\title{
THE ROLE OF EDUCATIONAL TOURISM FOR INDONESIAN DEVELOPMENT
}

\author{
Kadek Ayu Ekasani, Ni Kadek Ajeng Wangi Bhuanaputri, Paulin Yosephanny, \\ Felicia Johny Alberta \\ Institut Pariwisata dan Bisnis Internasional, Indonesia \\ ekasani@stpbi.ac.id
}

\begin{abstract}
Educational Tourism is one of the types of tourism in Indonesia. There are still limited studies that attempt to discover the relationship between tourism education and education tourism (edu-tourism). Educational Tourism is one of the types of tourism activities that has been recognized by the Indonesian government, which is a field trip related to an activity or trip whose purpose is for recreation or entertainment and contains educational activities in it. The data method is done by interview was used in collecting the data to get some information from local people or society, and data is descriptive qualitative. The results showed that English educational tourism through the phenomenon of Kampung Inggris is one of the Educational Tourism destinations in Indonesia. Educational Tourism has many benefits, such as creating jobs, improving the educational system, and increasing young generations' competitiveness. The role of education can make the country is able to have highly developed and foremost competitiveness.
\end{abstract}

Keyword: Educational Tourism; Phenomenon of Kampung Inggris; Tourism Sector

\section{INTRODUCTION}

Tourism is one of the most important sectors in Indonesia, which ranks fourth in terms of foreign exchange earnings after oil, natural gas, and palm oil commodities occupy the top positions. The tourism sector in Indonesia also has a very large impact in the economic, political, social and cultural fields. The types of tourism activities that are found in Indonesia, among others, Natural Tourism, Religious Tourism, Shopping Tourism, Culinary Tourism, Cultural Tourism, Sports Tourism, Agro Tourism, Political Tourism or Conventions, and Educational Tourism. As for what is often the basis of tourism in Indonesia is Nature and Culture Tourism. The trends that occur in the tourism sector in Indonesia are more focused on Nature Tourism and Cultural Tourism. However, there is one type of tourism activity that has not been developed too much, especially in Indonesia, namely Education Tourism. Education Tourism is one of the types of tourism activities that has been recognized by the Indonesian government, which is a field trip related to an activity or trip whose purpose is for recreation or entertainment and there are educational activities in it. Tourism science or studies has been taught at the higher levelbecause it could contribute to customer satisfaction and the competitiveness of 
the tourism business (Malihah \& Setiyorini, 2014). There was an increasing number of universities in the world which focus on hospitality and Tourism Programs (Kim et al., 2008) in Malihah \& Setiyorini (2014).

Tourism in recent times has been widely seen as one which has contributed tremendously to the economy of most destination areas, improving their foreign exchange, creating jobs, creating awareness, improving standards of living and contributing to image-building of destination areas, it is pertinent to note that most developing countries in the world today benefit so much from tourism without recognizing the real impact such tourism activities has on its economy based on the trickle-down nature of tourism benefits to its host (Okech, 2008 in Sharma, 2015). Tourism education was developed for preparing the human resources at the tourism business and industry. According to the Minister of Villages, Disadvantaged Regions and Transmigration, Pembangunan Daerah Tertinggal dan Transmigrasi (PDTT), the Indonesian government focused on empowering the economy and resources to rural communities in disadvantaged, frontier and outermost areas. The development of Tulungrejo Village into Kampung Inggrisis a phenomenon that is able to help the economy in Tulungrejo Village after becoming Kampung Inggris. The phenomenon is one example of the development of tourist destination based on Tourism sector especially for Educational Tourism in Indonesia.

A few researchers focused on the history of Kampung Inggris, such as from Anitasari (2012) in her published research entitled "Dari Desa Menjadi Kampung Inggris" elaborated about the story about Kampung Inggris before they even begun to make Tulungrejo Village as a Kampung Inggris. In this research elaborate about the Education Institution exists in Kampung Inggris and the impact of Educational Tourism in Tulungrejo Village. While this article focuses more on the discussion about the role of Kampung Inggris to local people and how the Government handle this destination to be educational tourism.

\section{The Meaning of Edu-Tourism}

The teaching of tourism was first made into its own science taught in the City of Dubrovnik, Croatia in 1920. Leiper himself supports the development of tourism as his own science by calling "Tourismonology" as a Tourism Discipline. Tourism is one of the very important social institutions in modern life that can be learned. Tourism has history, literature, and has influence both internally and externally from both natural and cultural events. The existence of globalization and increasingly sophisticated technological developments make tourism managed and developed as much as possible. Lots of various kinds of entertainment provided. One of them is entertainment that is in demand by tourists, namely Educational Tourism. Tourism education refers to activities where tourists who are on vacation where they will travel to the location as a group with the main purpose to learn and gain experience from the location he or she visited directly (Rodger, 1998:28) in (Sharma, 2015). It can also be said that educational tourism is an activity carried out by tourists who are on an overnight vacation and those who travel for education and learning as a basis for their needs. These types of tours are then categorized into several types of culture, history, ecotourism, rural tourism, or study programs abroad. Through educational tours, there are also activities in the form of "long learning" which is an activity undertaken for the sake of learning to improve the 
skills or competencies that can be carried out either in the form of field trips, study tours, going to the public museum, and others.

\section{METHODOLOGY}

Descriptive qualitative method is a research method for this article, to explain an event that is taking place in the present and also in the past or experience of researchers. The ethnographic method (Ethnography) research is also used to observe social and lifestyle or cultural conditions in Indonesia. The interview was used in collecting the data to get some information from local people or society about the phenomenon of Kampung Inggris through Line Apps or online.

\section{RESULT AND DISCUSSION}

Motivations and Emotions are behaviour and important things in the Tourism Sector, especially in tourist or tourist destinations. Motivation has been conceived essentially as the driving force of human behaviour. The Emotions is the characters from the tourist when want to visit the tourist destination in the tourism sector, from this article we can know the motivations or the reason why the tourist want to trip or travel. The people who are interested in doing educational tourism mostly have their own push factors to do that. Since the first time they choose the destination, there is a background why they want to study in a destination to improve their knowledge. There are few push factors of educational tourism such as:

1. New Experience

The people who are interested to do educational tourism program definitely will like to have a new experience to study abroad or outside from their town to experience new things that may they have not done it before.

2. Expand their knowledge and perspectives

The students may want to increase their knowledge and open up their mind to have a broad insight and see the world from another point of view.

\section{Self-motivated}

The people who are interested to take educational tourism program may want to embrace their challenge in life to try new experience in somewhere else and they want to have a good job opportunity after they have finished the educational tourist program.

\section{Synergy of Educational Tourism for Sustainable Tourism}

Tourism studies have been taught at a high level because tourism itself contributes greatly to the well-being of human life. Tourism studies also provide satisfaction to tourists or customers and increase the competitiveness of tourism businesses to improve the potential of tourism power towards a better direction. Kim et al. (2008) in Malihah \& Setiyorini (2014) said more and more universities around the world were focusing on the study of hospitality and tourism programs. Tourism education was developed with the aim of preparing quality human resources when plunging into the tourism and hospitality industry. According to Hjalger (2003: 33-34) in Malihah \& Setiyorini (2014) states that there should be a close relationship between stakeholders and educational institutions which is a rare one towards a professional attitude towards the whole sector and to increase knowledge and the ability to innovate. Zanogari (2009: 7) in Malihah \& Setiyorini 
(2014) also helped strengthen the idea stating that there should be a policy on education and even the existence of a tourism training program that provides a balance between skills, professionalism, basic knowledge, to meet the needs of the tourism and hospitality industry. There are studies or teachings in Bali about Tri Hita Karana which are applied in the tourism and hospitality industry and even this learning is taught at tourism and hospitality universities. The Tri Hita Karana Program was established with a view to building Balinese tourism in a sustainable and harmonious manner towards the environment.However, on the other hand there are many problems caused by tourism activities such as environmental pollution, traffic congestion, environmental damage to the transfer of land functions, especially agriculture (Dibya, 2018).

Local people have a bad stigma related to tourism development which is considered not to have much influence on people's lives, and the benefits of tourism development are only enjoyed by a few people. Therefore, there is a solution that is through the Tri Hita Karana program. Tri Hita Karana is based on harmony of life which consists of three elements, namely parahyangan, pawongan, palemahan that mutually influencing one another. Parahyangan refers to the harmony between human relations and God Almighty. Pawongan refers to harmony with relationships between human beings, and palemahan refers to harmony with relations with the environment and the natural surroundings. The implementation of Tri Hita Karana is seen as one of the most effective solutions in maintaining tourism in Bali. This was later proven by research conducted by (Agung \& Agung, 2012), which proves that the Balinese philosophy of Tri Hita Karana is one of the best philosophies to preserve Balinese customs, culture and nature. Tri Hita Karana is the best philosophy to flexibly adapt the effects of globalization and conserve the identity, traditions and culture of the Balinese people (Suara Pembaharuan, 2002). Through the implementation of Tri Hita Karana, the development of tourism in Bali can lead to sustainable tourism. Where through, sustainable tourism can increase income, and provide opportunities for employment opportunities.

\section{English Educational Tourism Through The Phenomenon of Kampunginggris}

From the village to Kampung Inggris is one of the phenomenon Educational Tourism for Tulung rejo village. Kampung Inggris is a term for Tulungrejo Village, Pare subdistrict, Kediri regency because of its ability to develop English language courses. The presence of Kampung Inggris has been able to push up Tulungrejo village is one of the famous of new investment in the District of Pare and surrounding areas. Since in the 1980s, the number of tutoring is still a matter of fingers, but now, there are already around 146 tutoring institutions in Tulungrejo Village and 20 in Pelem Village. These two villages have been transformed into Educational Tourism Villages. No wonder many residents from outside the area visited to study in Kampung Inggris, a distance of $23.5 \mathrm{~km}$ and taken about 30 minutes from the City of Kediri.

The economy of the Tulungrejo village community is closely related to the growth of the course institutions. The economic system applies Kalandisme system in which educational institutions as economic initiators are an important part whose job is to be the heartbeat of the surrounding economic movements. Kampung Inggris has around 102 institute courses and every year is visited by no less than 50 thousand tourists with various ages to attend an English course and recreation. 
Visitors are not only from students but also adults who want to explore English. They are also from various regions in Indonesia, even from abroad. In Kediri District, Kampung Inggris is one of the destinations for migrants. It also has a positive effect on the residents in the vicinity, including the economic wheels that are running, as well as increasing various tourist visits in the vicinity.

\section{The Impact of Educational Tourism}

The concept of tourism and education could be one of the potentials for some places in Indonesia to develop their tourism field. This concept has been around for a long time. Still, only a few regions in Indonesia have implemented educational tourism in their area, such as in the Kampung Inggris, Pare, East Java. Educational Tourism could have many effects on an area. Besides having an impact on the region, educational tourism will also have an impact on interested ones after they have finished the educational tourism program. There two sides of impact from Educational Tourism which are Positive Impact and Negative Impact.

\section{A. Positive Impact of Educational Tourism}

1. Economic Growth

Educational tourism definitely will make a huge contribution to the area. The students are obviously spending their money or expenditures in stores, restaurants or the other primary needs of human in a state.

2. Multiplier Effect

The resident or area could have an opportunity to build the multiplier effect on the local residents to provide the needs of the students. Towards educational tourism, the students will have a program where they could go to sightseeing in the surrounded area. It may be a chance for nearby tourist attractions to get an income by the student visit.

3. Socio-Cultural

The students of educational tourism program could build a better-quality perception in the residents. Due to many students are coming from different parts of the country or even the world, it could make a two-way communication between the students and the locals. Thus, there will be a cultural exchange between them and both sides could build a different relationship to one another either its local or also a student.

4. New Job Opportunities

The schools that are providing the educational tourism program will open the new job opportunities for the local residents. For example, the school will find a person who would like to be the security, library man or even the administrative staff and teachers.

5. Increased Knowledge

The students may have learned something in a resident such as language or culture and it could make them have a broad insight and understand new things.

6. Environmental

Educational Tourism could improve the environment surrounding the school and the resident. In Malaysia, it proved that Educational Tourism had improved its transportation system (Samah et al., 2012). 


\section{New Destination}

The resident or the town could be a new destination for the students who are interested in doing educational tourism.

\section{B. Negative Impact of Educational Tourism}

1. Lack of Statistical Data

The academic management could face the problem of having a lack of statistical data about the schools or the students.

2. Language Barrier

The students are coming from different part of a country or the world, so one challenge that they may have is language barrier where they hardly understand and it could make a conflict between them (Quezada, 2004).

\section{The Differences Between Educational Tourism in Indonesia and Foreign Country}

Educational Tourism is one of the type tourisms in Indonesia. The development of tourism sector in Indonesia always increases to avoid stagnation of phase. However Educational Tourism is tourism has not been commonplace, the society in Indonesia only know the purpose of tourism to recreation and business for getting income and foreign exchange. Increasing of Educational Tourism not very impactful for Indonesia, which because society is still reluctant to travel on an educational basis. Over time, the government of Indonesia focused on the importance of educational for the younger generation. Several publics and private schools or institution has conducted study tour programs (Study Banding) go to historic tourist destinations such as Museums, Existing Temple (Candi) in Indonesia and student exchange programs, well the students know the International of education system to increase competitiveness of students. Educational Tourism in foreign country is commonplace, people abroad are very enthusiastic about a more advanced education system and have a different curriculum with Indonesia. The role of the government in Kampung Inggris is the role of legality, guidance, providing facilities, marketing, and the role of security. In fact, the role of the government is; still, there is no specific policy that helps the development of nonformal education in Kampung Inggris. This role seems passive, more likely to contribute to the efforts that have been carried out by the community in developing the Kampung Inggris area.

\section{CONCLUSION}

Educational Tourism is one of type tourisms which has a lot of good impact and benefits such as educate the people of practising science, increasing for the economy of the system. Tourism education is developed for preparing human resources at the tourism business and industry. At the same time, educational tourism prepares human resource's skill, knowledge and open-minded people or society in Indonesia. Kampung Inggris is one of the tourist destinations that used the combination of educational and tourism in their program. This village has the uniqueness place in sharing the educational for local people and the visitors. For future research can combine this educational tourism with the digital era, how to 
elaborate the technology, education and tourism to be one educational system that can use for all institutions.

\section{REFERENCES}

Agung, G., \& Agung, A. (2012). Tri Hita Karana: A Primer in the Balinese Philosophy of Life and the Balance of Nature.

Anitasari, K. D. (2012). Dari Desa Menjadi Kampung Inggris (Kajian Sejarah Perekonomian Desa Tulungrejo Pare Kediri 1977- 2011).

Dibya, K. (2018). Pengembangan Pariwisata Berbasis Tri Hita Karana (Studi Pengembangan Pariwisata Berkelanjutan di Bali). Maha Widya Duta, 1(1), 56-63. http://jurnal.stahnmpukuturan.ac.id/index.php/duta/article/view/49

Malihah, E., \& Setiyorini, H. P. D. (2014). Tourism Education and Edu-Tourism Development: Sustainable Tourism Development Perspective in Education. The 1st International Seminar on Tourism (ISOT)-"Eco-Resort and Destination Sustainability: Planning, Impact, and Development, 1-7.

Quezada, R. L. (2004). Beyond educational tourism: Lessons learned while student teaching abroad. International Education Journal, 5(4), 458-465.

Rodger. (1998). Leisure, learning and travel. Journal of Physical Education, Research and Dance, 69(4), 28-31.

Samah, A. A., Ahmadian, M., Gill, S. S., \& Hendijani, R. B. (2012). Factors affecting educational tourism development among local communities in the Klang Valley, Malaysia. Life Science Journal, 9(4), 3298-3303.

Sharma, A. (2015). Educational tourism: strategy for sustainable tourism development with reference of Hadauti and Shekhawati regions of Rajasthan, India. Journal of Business Economics and Information Technology, 11(4), 112.

Suara Pembaharuan. (2002). Lestarikan Bali Dengan Tri Hita Karana. www.hinduindonesia.com 